\title{
Enzyme Activities of Liver Function (Biomarkers) in Sickle Cell Anaemic Patients Attending Sickle Cell Anaemic Centre, Benin City, Edo State, Nigeria
}

\author{
Collins Uchechukwu Obi ${ }^{1,2}$, Okikioluwa Stephen Aladeyelu ${ }^{3 *}$ (D) , ljeoma NnennaAgbiogwu ${ }^{1}$, \\ Nneka Chidimma Agu ${ }^{1}$, Joseph Akinwale Arusiwon ${ }^{4}$ and Mercy Oluchukwu Udeh ${ }^{1}$
}

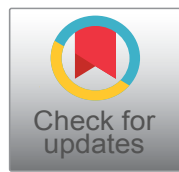

${ }^{1}$ Department of Medical Laboratory Science, Faculty of Health Science, University of Nigeria, Enugu Campus, Enugu State, Nigeria

${ }^{2}$ Department of Medical Laboratory Science, Faculty of Basic Medical Sciences, College of Medicine, Ambrose Ali University, Ekpoma, Edo State, Nigeria

${ }^{3}$ Discipline of Clinical Anatomy, School of Laboratory Medicine and Medical Sciences, College of Health Sciences, Nelson R Mandela School of Medicine Campus, University of Kwazulu-Natal, Durban, South Africa

${ }^{4}$ Department of Anatomy, Faculty of Basic Medical Sciences, Nnamdi Azikiwe University, Nnewi Campus, Anambra State, Nigeria

*Corresponding author: Okikioluwa Stephen Aladeyelu, Discipline of Clinical Anatomy, School of Laboratory Medicine and Medical Sciences, College of Health Sciences, Nelson R. Mandela School of Medicine Campus, University of KwazuluNatal, Durban, South Africa, Tel: +27-656-975-373; +23-48036982473

\begin{abstract}
Sickle cell anaemia is a genetic disorder and the commonest severe monogenic disorders in human resulting from the presence of a mutated form of hemoglobin, hemoglobin S. This study aimed to investigate the enzyme activities in liver function of sickle cell anaemic patients.

Hundred subjects were involved for this study. The subjects were divided into 2 groups: 50 sickle cell anaemic subjects (20 males and 30 females) and 50 non-sickle cell subjects or control (23 males and 27 females). Sickle cell anaemic subjects were between the age ranges of 15-41 years while control subjects were between 17-31 years. Subjects were both Sickle Cell Anaemic Centre, Benin City, Edo State, Nigeria and volunteer students at the Department Medical Laboratory Science, Ambrose Ali University Ekpoma, Nigeria. Clinical diagnosis of patients was confirmed by Haemoglobin electrophoresis. Enzyme activities of serum GGT, ALT and AST, levels of total protein and albumin were assayed by colorimetric methods. The results showed that serum GGT, ALT and AST in sickle cell anaemic patients were significantly higher $(p<0.05)$ which could be due to liver ischaemia, cholestasis or vaso-occlusive crisis involving the bone, liver enlargement seen in sickle cell patients and presence of numerous sickled red blood cells in the lobular
\end{abstract}

parenchyma of the liver respectively while levels of total protein and albumin (ALB) were significantly low $(p<0.05)$ when compared with control subjects which could be as a result of the quick fall of concentration of short lived hepatic proteins and loss of albumin into ascetic fluid respectively. There was no significant difference in sex related distributions of sickle cell anaemic patients. There was still no significant difference in stratified age groups (15-20 and 21-41 years) of liver function tests in sickle cell anaemic patients. It was concluded from this study that increased serum activities of GGT, ALT and AST, and low levels of total protein and albumin, may be a valuable index in the diagnosis and monitoring of patients with sickle cell anaemia.

\section{Keywords}

Sickle cell, Anaemia, Liver, Enzyme

\section{Introduction}

Sickle-cell anemia is a hereditary blood disease caused by a defective gene that produces an abnormal form of hemoglobin, the component of red blood cells responsible for transporting oxygen from the lungs to the tissues. The abnormal hemoglobin, called hemoglo-

Citation: Obi CU, Aladeyelu OS, Agbiogwu IN, Agu NC, Arusiwon JA, et al. (2020) Enzyme Activities of Liver Function (Bio-makers) in Sickle Cell Anaemic Patients Attending Sickle Cell Anaemic Centre, Benin City, Edo State, Nigeria. Int J Blood Res Disord 7:057. doi.org/10.23937/2469-5696/1410057 Accepted: September 21, 2020: Published: September 23, 2020

Copyright: (C) 2020 Obi CU, et al. This is an open-access article distributed under the terms of the Creative Commons Attribution License, which permits unrestricted use, distribution, and reproduction in any medium, provided the original author and source are credited. 
bin S, distorts red blood cells after they release oxygen in the tissues. These distorted cells are called sickled cells [1].

Sickle cell disease affects millions of people throughout the world and is particularly common among those whose ancestors came from sub-Saharan Africa, South America, the Caribbean, Central America, Saudi Arabia, India and Mediterranean countries (such as Turkey, Greece, and Italy) [2]. It is a multi systemic disorder affecting about 1 in 500 African Americans. Approximately, 300,000 infants are born with it annually [3].

Sickle cell anaemia is probably the commonest known hereditary blood disorders in Nigeria [4,5]. The sickle cell anaemia (SS) is the homozygous state in which the sickle gene is inherited from the father and the mother. Sickle cell disease may also occur in a heterozygous form in conjunction with other haemoglobin beta chair abnormalities [6,7].

In 1949, the genetic basis for sickle cell anaemia was demonstrated (Beet, 1999), in which the heterogenicity of the sickle cell gene results in sickle cell trait while homogenicity leads to sickle cell anaemia [8]. The sickling occurs because of a mutation (change in the genetic material (DNA) of a cell) in the haemoglobingene. Life expectancy is shortened, with studies reporting an average life expectancy of 42 in males and 48 in females [9].

Sickle cell anaemia, usually presenting in childhood, occurs more commonly in people (or their descendants) from parts of tropical and sub-tropical regions where malaria is or will be common. One-third of all indigenous inhabitants of Sub-Saharan Africa carry the gene, because in areas where malaria is common [10,11]. In some regions of the world, sickle cell anaemia is almost endemic and the highest mortality rate is among children from 1 to 10 years of age [12].

Two-third of people suffering from the disease comes from a very low socio-economic level. However, in certain parts of the country, better living conditions, nutrition and medical care have resulted in significant reduction in mortality [13].

The liver is a vital organ present in vertebrates and some other animals. It has a wide range of functions, including detoxification, protein synthesis, and production of biochemical necessary for digestion. The liver is necessary for survival; there is currently no way to compensate for the absence of liver function [14].

Hepatic disease (Liver disease) is a commonly recognized complication of sickle cell anaemia due to multiple factors such as intra-hepatic sinusoidal sickling, bilirubin, gallstones, transfusion related hepatitis infections or excess iron deposition [15]. Clinical evidence of hepatic dysfunction in patients with sickle cell disease was explained by trapping of sickle cells during passage through the hepatic sinusoids which are engulfed by phagocytes causing hepatomegaly [16].
In clinical chemistry a number of tests are performed which are useful in the assessment of liver functions, diagnosing, monitoring and understanding the prognosis of liver diseases.

This study aims to assess the enzyme activities of serum Glutamyl transpeptidase (GGT), Alanine transaminase (ALT), Aspartate transaminase (AST) and levels of total protein and albumin in sickle cell anaemia.

\section{Materials and Methods}

\section{Study area and population}

This study was carried out in Sickle Cell Anaemic Centre, Benin City, is the capital of Edo State. Edo State lies roughly between longitude $06^{\circ} 04^{1} \mathrm{E}$ and $06^{\circ} 43^{1} \mathrm{E}$ and latitude and latitude $05^{\circ} 44^{1} \mathrm{~N}$ and $07^{\circ} 34^{1} \mathrm{~N}$ with a land mass of 17,450 sq. $\mathrm{Km}$ and located in the South-South geopolitical zone of Nigeria with a population of $3.1 \mathrm{mil}-$ lion people as at the time of this study.

\section{Subjects}

Sickle cell subjects were patients who visited Sickle Cell Centre, Benin City, Edo State, Nigeria from October to November, 2010. Subjects were fifty (50) sickle cell anaemic patients, 20 males and 30 females aged 15 to 41 years. Fifty (50) apparently healthy (volunteer) control subjects, 23 males and 27 females aged 17 to 31 years, served as the group. Clinical diagnosis of patients was confirmed by haemoglobin electrophoresis.

\section{Ethical approval}

Ethical approval was obtained from the Ethical Management and Head of Unit, Sickle Cell Center Benin City, for the collection of samples for the purpose of this project work and one on one discussion was carried out with sickle cell anaemic patients for their voluntary participation. Ethical approval was also obtained from the Ethics Committee of Faculty of Basic Medical Sciences, Ambrose Ali University, Ekpoma, Edo State for the use of students in the faculty who served as healthy volunteers.

\section{Inclusion criteria}

Already diagnosed sickle cell anaemic patients and apparently healthy volunteered males and females (non-sickle cell anaemic) who have no history of liver diseases were recruited for the study.

\section{Parameters for the study}

The parameters used for these purpose include: Enzyme activities of serum Glutamyl transpeptidase (GGT), transaminases (Alanine transaminase (ALT), Aspartate transaminase (AST), levels of total protein (TP) and albumin (ALB).

\section{Sample collection}

$4.0 \mathrm{ml}$ 's of venous blood sample was collected from 
each subject using a $5.0 \mathrm{ml}$ 's sterile disposable syringe. This was dispensed into a $5 \mathrm{ml}$ 's plain sample containers labelled with the subject's name, age and sex. The blood was spun for 5 minutes at $3000 \mathrm{rpm}$. The serum was separated from the red cells using a dry clean Pasteur pipette into a dry clean plain specimen container. The serum was then stored at $-20^{\circ} \mathrm{C}$. Enzyme activity assay was carried out for GGT, AST and ALT. Levels of Total protein and Albumin were also estimated.

\section{Statistical analysis}

The results obtained in this study were analyzed statistically. The mean and Standard deviation values were calculated in each case. Student's t-test statistical method was employed for comparisons using SPSS. The comparison was done at $95 \%$ confidence level, a $p$-value equal to or less than $0.05(p \leq 0.05)$ were considered statistically significant.

\section{Results}

The results obtained in the investigations are presented in Table 1, Table 2, Table 3, Table 4 and Table 5. All results are Mean \pm SD.

\section{Discussion}

Sickle cell anaemia is the condition resulting from the inheritance of two abnormal allele-morphic genes controlling $\beta$-globin formation of which at least one is the $\beta^{s}$ gene. A point mutation replaces glutamic acid with valine at sixth position on the $\beta$ globin. The combination of normal $\alpha$ chains with the abnormal $\beta^{s}$ chains forms sickle haemoglobin (HbS).

The results of liver function tests in patients with sickle cell disease when compared with controls showed a statistical significant difference in the enzyme activities of serum glutamyl transpeptidase (GGT), transaminases (Alanine Transaminase and Aspartate transaminase), levels of total protein and albumin and its conjugated fraction $(P<0.05)$. These results obtained in this study are in agreement with those reported by Doumas, et al., Brittenham, et al., McGlynn, et al., Hamatz, et al., Cage and Kotila, et al. [17-22].

Enzyme activities of serum GGT, ALT and AST obtained from sickle cell patients were generally higher and low levels of total protein and albumin were observed when compared with the control subjects. These findings agree with the reports of Omata, et al., Roshkow and Sanders; Hamatz, et al.; Paul and Giboney [20,23-25].

The observed high activities of serum GGT in sickle cell patients can be attributed to both bone and liver complications usually associated with sickle cell anaemia. This was also reported by Cage; Berk and Korenblat $[21,26]$, That the increased serum GGT could be due to liver ischaemia, cholestasis or vaso-occlusive crisis involving the bone.

Table 1: Serum GGT, ALT, AST activities, levels of TP and ALB in sickle cell anaemic patients and controls in the study.

\begin{tabular}{|l|l|l|l|l|}
\hline Parameters & $\begin{array}{l}\text { Patients } \\
\mathrm{n}=50\end{array}$ & $\begin{array}{l}\text { Controls } \\
\mathrm{n}=50\end{array}$ & t-value & -value \\
\hline GCT & $28.31 \pm 12.68 \mathrm{U} / \mathrm{L}$ & $23.27 \pm 6.95 \mathrm{U} / \mathrm{L}$ & 2.5 & $<0.05(\mathrm{~S})$ \\
\hline ALT & $29.64 \pm 13.32 \mathrm{U} / \mathrm{L}$ & $24.12 \pm 9.66 \mathrm{U} / \mathrm{L}$ & 2.4 & $<0.05(\mathrm{~S})$ \\
\hline AST & $42.14 \pm 25.10 \mathrm{U} / \mathrm{L}$ & $21.30 \pm 6.73 \mathrm{U} / \mathrm{L}$ & 5.7 & $<0.05(\mathrm{~S})$ \\
\hline TP & $6.18 \pm 1.27 \mathrm{~g} / \mathrm{dL}$ & $7.58 \pm 1.34 \mathrm{~g} / \mathrm{dL}$ & 5.4 & $<0.05(\mathrm{~S})$ \\
\hline ALB & $4.28 \pm 0.82 \mathrm{~g} / \mathrm{dL}$ & $5.27 \pm 0.92 \mathrm{~g} / \mathrm{dL}$ & 6.0 & $<0.05(\mathrm{~S})$ \\
\hline & & $\mathbf{d f = 9 8 ;} \mathbf{p}<\mathbf{0 . 0 5}$ & & \\
\hline
\end{tabular}

This table shows the serum GGT, ALT and AST activities of patients with sickle cell anaemia as significantly higher (p $<0.05)$ while the levels of total protein and albumin of patients with sickle cell anaemia were significantly low $(p<0.05)$ when compared with the control subjects.

Table 2: Serum GGT, ALT, AST activities, levels of TP and ALB in sickle cell in male and female patients with sickle cell anaemia in the study.

\begin{tabular}{|l|l|l|l|l|}
\hline Parameters & Male & Female & t-value & -value \\
& $\mathrm{n}=20$ & $\mathrm{n}=30$ & & $>0.05(\mathrm{NS})$ \\
\hline GCT & $33.00 \pm 13.79 \mathrm{U} / \mathrm{L}$ & $25.18 \pm 11.04 \mathrm{U} / \mathrm{L}$ & 1.8 & $>0.05(\mathrm{NS})$ \\
\hline ALT & $29.00 \pm 13.79 \mathrm{U} / \mathrm{L}$ & $30.07 \pm 13.22 \mathrm{U} / \mathrm{L}$ & 0.28 & $>0.05(\mathrm{NS})$ \\
\hline AST & $41.40 \pm 25.31 \mathrm{U} / \mathrm{L}$ & $42.63 \pm 25.38 \mathrm{U} / \mathrm{L}$ & 0.17 & $>0.05(\mathrm{NS})$ \\
\hline TP & $6.53 \pm 1.45 \mathrm{~g} / \mathrm{dL}$ & $5.90 \pm 1.09 \mathrm{~g} / \mathrm{dL}$ & 1.75 & $>0.05(\mathrm{NS})$ \\
\hline ALB & $4.76 \pm 0.85 \mathrm{~g} / \mathrm{dL}$ & $3.94 \pm 0.62 \mathrm{~g} / \mathrm{dL}$ & 1.9 & \\
\hline
\end{tabular}

This table shows the mean serum GGT, ALT, AST activities, levels of TP and ALB in male patients with sickle cell anaemia, when compared with those of females were not statistically significant $(p>0.05)$. 
Table 3: Serum GGT ALT, AST activities, levels of TP and ALB in male and female control subjects.

\begin{tabular}{|l|l|l|l|l|}
\hline Parameters & Male & Female & t-value & p-value \\
\hline GGT & $\mathrm{n}=23$ & 27 & & $>0.05$ (NS) \\
\hline ALT & $22.28 \pm 5.27 \mathrm{U} / \mathrm{L}$ & $22.68 \pm 5.29 \mathrm{U} / \mathrm{L}$ & 0.26 & $>0.05(\mathrm{NS})$ \\
\hline AST & $26.74 \pm 11.20 \mathrm{U} / \mathrm{L}$ & $23.04 \pm 8.49 \mathrm{U} / \mathrm{L}$ & 1.3 & $>0.05(\mathrm{NS})$ \\
\hline TP & $21.78 \pm 7.19 \mathrm{U} / \mathrm{L}$ & $20.62 \pm 6.82 \mathrm{U} / \mathrm{L}$ & 0.6 & $>0.05(\mathrm{NS})$ \\
\hline ALB & $7.40 \pm 1.50 \mathrm{~g} / \mathrm{dL}$ & $7.81 \pm 1.12 \mathrm{~g} / \mathrm{dL}$ & 1.10 & $>0.05(\mathrm{NS})$ \\
\hline & $5.26 \pm 0.94 \mathrm{~g} / \mathrm{dL}$ & $5.37 \pm 0.65 \mathrm{~g} / \mathrm{dL}$ & 0.5 & \\
\hline
\end{tabular}

This table shows that the mean serum GGT, ALT, AST activities, levels of TP and ALB in males and females control subjects, showed no statistically significant difference $(p>0.05)$ in the values obtained in males when compared with females.

Table 4: Age related distribution of Serum GGT, ALT, AST Activities, levels of TP and ALB in sickle cell anaemic patients in study.

\begin{tabular}{|l|l|l|l|l|}
\hline Parameters & $\begin{array}{l}15-20 \text { (Years) } \\
\mathrm{n}=22\end{array}$ & $\begin{array}{l}21-41 \text { (Years) } \\
\mathrm{n}=28\end{array}$ & t-value & p-value \\
\hline GGT & $25.59 \pm 12.42 \mathrm{U} / \mathrm{L}$ & $30.11 \pm 13.31 \mathrm{U} / \mathrm{L}$ & 1.2 & $>0.05(\mathrm{NS})$ \\
\hline ALT & $31.73 \pm 11.73 \mathrm{U} / \mathrm{L}$ & $28.00 \pm 14.54 \mathrm{U} / \mathrm{L}$ & 1.0 & $>0.05(\mathrm{NS})$ \\
\hline AST & $40.06 \pm 20.43 \mathrm{U} / \mathrm{L}$ & $43.79 \pm 28.50 \mathrm{U} / \mathrm{L}$ & 0.5 & $>0.05(\mathrm{NS})$ \\
\hline TP & $6.48 \pm 1.08 \mathrm{~g} / \mathrm{dL}$ & $5.89 \pm 1.37 \mathrm{~g} / \mathrm{dL}$ & 1.7 & $>0.05(\mathrm{NS})$ \\
\hline ALB & $4.31 \pm 0.76 \mathrm{~g} / \mathrm{dL}$ & $4.23 \pm 0.87 \mathrm{~g} / \mathrm{dL}$ & 0.3 & $>0.05(\mathrm{NS})$ \\
\hline & & $\mathrm{df}=48 ; \mathrm{p}>0.05$ & & \\
\hline
\end{tabular}

This table also discloses the mean serum GGT, ALT, AST activities, levels of TP and ALB of the age groups 15-20 years and 2141 years in patients with sickle cell anaemia, showed no statistical significant difference $(p>0.05)$ in the values obtained of age group 15-20 years when compared with age group 21-36 years.

Table 5: Serum GGT, ALT, AST activities, levels of TP and ALB in control subjects within the age groups 15-20 and 21-31.

\begin{tabular}{|l|l|l|l|l|}
\hline Parameters & $\begin{array}{l}15-20 \text { (Years) } \\
\mathrm{n}=13\end{array}$ & $\begin{array}{l}21-31 \text { (Years) } \\
\mathrm{n}=37\end{array}$ & t-value & p-value \\
\hline GGT & $23.98 \pm 9.32 \mathrm{U} / \mathrm{L}$ & $23.02 \pm 6.05 \mathrm{U} / \mathrm{L}$ & 0.4 & $>0.05$ (NS) \\
\hline ALT & $25.70 \pm 7.65 \mathrm{U} / \mathrm{L}$ & $23.57 \pm 10.31 \mathrm{U} / \mathrm{L}$ & 0.7 & $>0.05(\mathrm{NS})$ \\
\hline AST & $18.69 \pm 7.42 \mathrm{U} / \mathrm{L}$ & $22.22 \pm 6.32 \mathrm{U} / \mathrm{L}$ & 1.7 & $>0.05(\mathrm{NS})$ \\
\hline TP & $7.52 \pm 1.54 \mathrm{~g} / \mathrm{dL}$ & $7.67 \pm 1.23 \mathrm{~g} / \mathrm{dL}$ & 0.4 & $>0.05(\mathrm{NS})$ \\
\hline ALB & $5.28 \pm 0.92 \mathrm{~g} / \mathrm{dL}$ & $5.31 \pm 0.76 \mathrm{~g} / \mathrm{dL}$ & 0.11 & $>0.05(\mathrm{NS})$ \\
\hline & & $\mathrm{df}=48 ; \mathrm{p}>0.05$ & & \\
\hline
\end{tabular}

This table indicates that the mean serum GGT, ALT, AST activities, levels of TP and ALB of age group 15-20 years and 21-31 years in control subjects, showed no statistical significant difference $(p>0.05)$ in the values obtained from the age group $15-20$ years when compared with age groups 21-31 years.

The observed high enzyme activity of ALT was in agreement with those reported by Johnson, et al., Kotila, et al. [22,27] who explained that liver enlargement seen in sickle cell patients is not due solely to hepatic disease because abnormality of ALT which is specific for hepatic injury. The observed high activity of AST in patients with sickle cell anaemia could be as a result of the presence of numerous sickled red blood cells in the lobular parenchyma of the liver $[25,28]$.

The observed low levels of total protein and albumin in patients with sickle cell anaemia could be as a result of the quick fall of concentration of short-lived hepatic proteins and loss of albumin into ascetic fluid respectively $[17,19]$.

The results of sex related distributions and the strat- ified age groups (15-20 and 21-above) showed no significance statistically $(p>0.05)$. This agrees with the reports of Omata, et al., Yeomans, et al. and Kotila, et al. $[22,23,29]$.

\section{Conclusion}

It can be concluded from this study that increased serum activities of GGT, ALT, AST and low levels of total protein and albumin concentration were observed. These increases in the enzyme activities and low levels of total protein and albumin concentration which are not gender or age related reflect chronic liver injury.

\section{References}

1. Aster JC (2004) Red blood cell and bleeding disorders. In: Kumar V, Abbas AK, Nelson F. Robbins and Cotrans 
Pathologic Basis of Disease Philadelphia: Elservier Saunders.

2. Center for Disease Control and Prevention (2019) Sickle cell disease.

3. Sedrak A, Kondamud NP (2019) Sickle cell disease. In: StatPearls. Treasure Island: StatPearls Publishing.

4. David HG, Bridgman SA, Davies SC, AL Hine, RJ Emery (1993) The shoulder in sickle cell disease. J Bone Joint Surg 75: 538-545.

5. Ballas SK (1995) The sickle cell painful crisis in adults: Phases and objective signs. Haemoglobin 19: 323-333.

6. Iwegbu CG, Fleming AF (1985) Avascular necrosis of the femoral head in sickle cell disease: A series from the Guinea savannah of Nigeria. J Bone Joint Surg 67: 29-32.

7. Smith WR, Penberty LT, Bovbjerj VE (2008) Daily assessment of pain in adults with sickle cell disease. Ann Intern Med 148: 94-101.

8. Ned JV, Bertles JF, Wether DL (1973) Sickle cell disease: A worldwide problem. eds. Sickle Cell Disease: Inheritance, diagnosis, management, education and research. 122: 123-154.

9. Platt OS, Brambilla DJ, Rosse WF, PF Milner, O Castro, et al. (1994) Mortality in sickle cell disease. Life expectancy and risk factors for early death. N Engl J Med 330: 16391644.

10. Itano HA (1993) Qualitative control of adult haemoglobin synthesis: A multiple allele hypothesis. Am J Hum Genet 5: 34-36.

11. Lawrence PR, Ryan KM, Harney KM (2000) Sickle cell in children providing comprehensive cure for a chronic condition. Adv Nurse Pract 8: 48-55.

12. Ward PA, Hejtmancik JF, Witkowski JA, Gunnel S, Speer J, Hawley PY (1998) Sickle cell endemicity. Am J Hum Genet 44: $270-281$.

13. World Health Organization (2008) Global sickle cell rate. Bulletin of World Health Organization 25: 27-30.

14. Wu JSY (2005) Classification of liver diseases. Br Med J 3: 4-6.

15. Kakarala S, Lindberg M (2004) Safety of liver biopsy in acute sickle hepatic crisis. Conn Med 68: 277-279.

16. Beutler E (1999) The sickle cell disease and related disorders. In: Beutler E, Lichtman MA, Coller BS, Kipps TJ,
Seligsohn U (eds). Williams Haematology New York: McGraw Hill.

17. Doumas BT, Wastson WA, Biggs HG (1971) The human version is humanserum albumin. Clinical Chim Acta 3: 87.

18. Brittenham GM, Cohen AR, Mc Laren CE, MB Martin, PM Griffith, et al. (1993) Hepatic iron stores and plasma ferritin concentration in patients with sickle cell anaemia and thalassaemia. Am J Hematol 42: 81-85.

19. McGlynn K, Rosvold E, Lustbade E, Hu Y, Clapper M, et al. (1995) Susceptibility to hepatocellular carcinoma is associated with genetic variation in the protein denaturalization of afflation. Proc Natl Acad Sci 92: 2384-2387.

20. Harmatz P, Buteusky E, Quirolo K, R Williams, L Ferrell, et al. (2000) Severity of iron overload in patients with sickle cell disease receiving chronic red blood cell transfusion therapy. Blood 96: 76-79.

21. Cage J (2001) Gall bladder and liver disorders in sickle cell disease: A critical review. Liver Diseases 8: 200-212.

22. Kotila TA, Kayode A, Aduragbenro A, Olayiowola O, Eyitayo $\mathrm{F}$, et al. (2005) Liver dysfunction in steady state sickle cell disease. Annals of Hepatol 4: 261-263.

23. Omata M, Johnson CS, Tong MJ, Simmons JF, Weiner J, et al. (1986) Pathological spectrum of liver disease in sickle cell disease. Dig Dis Sci 31: 247-257.

24. Roshkow JE, Sanders LM (1990) Acute splenic sequestration crisis in two adults with sickle cell disease: US, CT and MR imaging findings. Radiology 177: 723-725.

25. Paul T Giboney (2005) Mildly elevated liver transaminase levels in the asymptomatic patient. Am Fam Physician 71: 1105-1110.

26. SB Rosalki, D Tarlow, D Rau (1971) Plasma gamma-glutamyl transpeptidase elevation in patients receiving enzyme-inducing drugs. Lancet 2: 376-377.

27. Johnson CS, Omata M, Tong MJ, Tatter D (1985) Liver Involvement in sickle cell disease. Medicine (Baltimore) 64: 349-356.

28. Shao SH, Orringer EP (1995) Sickle cell intrahepatic cholestaisis: Approach to a difficult problem. Am J Gastroenterol 90: 2048-2050.

29. Yeomans E, Lowe T, Eigenbrodt EH, Cunningham FG (1990) Liver histopathologic findings in women with sickle cell disease given prophylactic transfusion during pregnancy. Am J Obstet Gynecol 163: 958-964. 